\title{
EDITORIAL
}

\section{Adjustable fortification of human milk fed to preterm infants}

\section{Journal of Perinatology (2006) 26, 591-592. doi:10.1038/sj.jp.7211576}

In adults, as protein intake increases, so does blood urea nitrogen (BUN), unless significant protein accretion is occurring and/or hepatic function; that is urea synthetic capacity, is compromised.

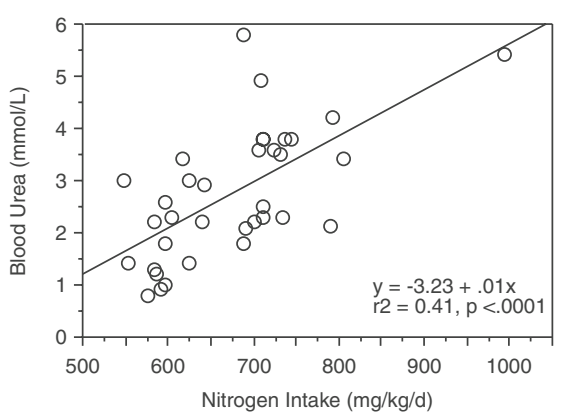

and SGA infant, (b) sex; that is, boys accrete more lean mass and grow faster than girls, ${ }^{15}$ (c) level of maturity; that is, protein:energy needs change with advancing gestation ${ }^{16}$ and (d) previous nutritional intake; that is, requirements for 'recovery' will vary. ${ }^{3}$ One formulation, therefore, is unlikely to meet the protein needs of all infants.

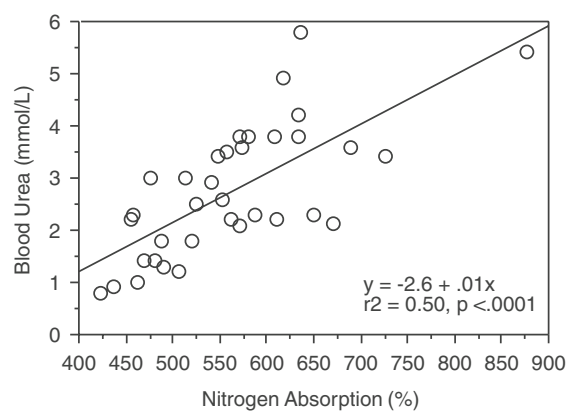

Figure 1 Relationship between BUN and nitrogen intake and nitrogen absorption.

When protein intake is low BUN is also low, unless renal or fluid status is compromised. ${ }^{1}$ In children, BUN changes rapidly with protein intake, assuming adequate hydration. ${ }^{2}$ Indeed, protein content of the diet can be directly related to the BUN; for example, if $8 \%$ of energy is protein then the BUN will be $\sim 8 \mathrm{mg} / \mathrm{dl}$ in the otherwise normal infant. ${ }^{2}$

The situation has been less clear-cut in preterm infants. It takes time to establish adequate energy intakes during early life in sick immature infant, ${ }^{3}$ protein is catabolized and BUN increases, irrespective of protein intake or renal function. At the same time, urea synthetic capacity ${ }^{4,5}$ and/or renal excretory ${ }^{6-8}$ may be limited in the immature infant. Thus, early studies suggested BUN is not a valid measure of protein intake in preterm infants. ${ }^{4,9-11}$

More recent studies, one by this group, ${ }^{12}$ suggest otherwise in the clinically stable preterm infant. ${ }^{13}$ In the latter study, the relationship between nitrogen accretion and growth fed two levels of protein intake, 3.0 and $3.6 \mathrm{~g} / 100 \mathrm{kcal}$, was assessed. Nitrogen intake varied widely but intake and absorption were linearly related to changes in BUN (see Figure 1) ${ }^{13}$ These data coupled with the findings in this study support the idea that, as in older children and adults, BUN is a valid measure protein intake in preterm infants.

The findings of this study, therefore, have important implications for feeding preterm infants. Protein requirements are not well established in preterm infants. ${ }^{14}$ Requirements will also vary depending upon (a) nutritional status at birth; that is, AGA
An additional consideration in this study is the wide variation in protein content of human milk ${ }^{17-20}$ that is rarely measured for individual mother-infant pairs. Irrespective of whether an infant is fed human milk or a preterm formula the idea that intake is 'tailored' to meet individual needs and is monitored to ensure efficacy, better growth and safety is a critical concept. The Arslanoglu et al paper in the current issue demonstrates that BUN determinations are an excellent index for adequacy of protein intake. This is a commonly overlooked, but important, message for day-to-day nutritional care in the neonatal intensive care setting.

RJ Cooke Neonatal-Perinatal Medicine, University of Tennessee Center for Health Sciences, Memphis, TN, USACorrespondence: Dr RJ Cooke, Neonatal-Perinatal Medicine, University of Tennessee Center for Health Sciences, 853 Jefferson Ave, Suite 201, Memphis, TN 38163, USA.

E-mail:rcooke@utmem.edu

\section{References}

1 Heimberger DC. Adulthood. In: Shils ME, Shike M, Ross AC, Caballero B, Cousins RJ (eds). Modern Nutrition in Health and Disease. Lippincott Williams \& Wilkins, 2006, pp 830-842.

2 Fomon S. Protein. In: Fomon SJ (ed). Nutrition of Normal Infants. Mosby: St Louis, 1993, pp 121-139. 
3 Embleton NE, Pang N, Cooke RJ. Postnatal malnutrition and growth retardation: an inevitable consequence of current recommendations in preterm infants? Pediatrics 2001; 107: 270-273.

4 Boehm G, Muller DM, Beyreiss K, Raiha NC. Evidence for functional immaturity of the ornithine-urea cycle in very- low-birth-weight infants. Biol Neonate 1988; 54: 121-125.

5 Morris Jr SM. Regulation of enzymes of urea and arginine synthesis. Ann Rev Nutr 1992; 12: 81-101.

6 Solhag MJ, Jose PA. Postnatal maturation of renal blood flow. In: Polin RA, Fox WW, Abman SH (eds). Fetal and Neontal Physiology. Saunders: Philadelphia, 2004, pp 1242-1249.

7 Guignard J-P. Postnatal development of glomerular filtration rate in neonates. In: Polin RA, Fox WW, Abman SH (eds). Fetal and Neontal Physiology. Saunders: Philadelphia, 2004, pp 1256-1266.

8 Feld LG, Corey HE. Renal transport of sodiumduring early development. In: Polin RA, Fox WW, Abman SH (eds). Fetal and Neontal Physiology. Saunders: Philadelphia, 2004, pp 1267-1278.

9 Boehm G, Teichmann B, Jung K. Development of urea-synthesizing capacity in preterm infants during the first weeks of life. Biol Neonate 1991; 59: 1-4.

10 Boehm G, Gedlu E, Muller MD, Beyreiss K, Raiha NC. Postnatal development of urea- and ammonia-excretion in urine of very-low-birth-weight infants small for gestational age. Acta Paediatrica Hungarica 1991; 31: 31-45.

11 Boehm G, Teichmann B, Jung K, Moro G. Postnatal development of urea synthesis capacity in preterm infants with intrauterine growth retardation. Biol Neonate 1998; 74: 1-6.
12 Moro GE, Minoli I, Ostrom M, Jacobs JR, Picone TA, Raiha NC, Ziegler EE. Fortification of human milk: evaluation of a novel fortification scheme and of a new fortifier. J Pediatr Gastroenterol Nutr 1995; 20: 162-172.

13 Cooke R, Embleton N, Rigo J, Carrie A, Haschke F, Ziegler E. High protein pre-term infant formula: effect on nutrient balance, metabolic status and growth. Pediatr Res 2006; 59: 265-270.

14 Klein CJ. Nutrient requirements for preterm infant formulas. J Nutr 2002; 132: $1395 \mathrm{~S}-1577 \mathrm{~S}$.

15 Cooke RJ, McCormick K, Griffin IJ, Embleton N, Faulkner K, Wells JC, Rawlings DC. Feeding preterm infants after hospital discharge: effect of diet on body composition. Pediatr Res 1999; 46: 461-464.

16 Ziegler EE, Thureen PJ, Carlson SJ. Aggressive nutrition of the very low birthweight infant. Clin Perinatol 2002; 29: 225-244.

17 Lemons J, Moye L, Hall D, Simmons M. Differences in the composition of preterm and term human milk during early lactation. Pediatr Res 1982; 16: 113-117.

18 Gross SJ, Geller J, Tomarelli RM. Composition of breast milk from mothers of preterm infants. Pediatrics 1981; 68: 490-493.

19 Anderson GH, Atkinson SA, Bryan MH. Energy and macronutrient content of human milk during early lactation from mothers giving birth prematurely and at term. Am J Clin Nutr 1981; 34: 258-265.

20 Michaelsen KF, Skafte L, Badsberg JH, Jorgensen M. Variation in macronutrients in human bank milk: influencing factors and implications for human milk banking. J Pediatr Gastroenterol Nutr 1990; 11: $229-239$. 